\title{
Anticipating Global Business Competition through Economic Democracy Principles
}

\author{
N L M Mahendrawati, I B Gede Agustya Mahaputra \\ Faculty of Law \\ Universitas Warmadewa \\ Denpasar-Bali, Indonesia \\ made.mahendrawati@gmail.com
}

\begin{abstract}
The emergence of online-based transport led to the emergence of a different competition model between the current and conventional transportation. The existence of conventional transportation began to be ruled out since the emergence of a system of use of online-based transport services, mainly in the area of tourism. Grounded on this, this paper is designed to reveal the economic democracy principles in anticipating the global business competition of tourism transportation by using normative juridical methods oriented towards conceptual and legislation approaches to transportation and fair business competition. The results show that there is an applicable theoretical model to the practice of anticipating unfair business competition in the field of tourism transportation. Theoretically, the principle of economic democracy is feasible to apply, especially to the economic democracy of The Five Principles of Indonesian Republic (Pancasila) as the basic principle in maintaining fair business competition in the field of transportation of Tourism in Indonesia. Regarding this, it is expected that every transport business actor has an equal access in order to obtain business resources based on the principles of economic democracy.
\end{abstract}

Keywords—principle of economic democracy; global business competition; tourism transportation

\section{INTRODUCTION}

Tourism when viewed from the standpoint of economic aspects is a sector that became the main focus of Indonesia's national economy. Statistical data from the Ministry of Tourism of Indonesia shows that the tourism sector is a type of commodity that provides a high amount of foreign exchange to the country. Around 2011-2015, tourism is ranked in the largest commodity row of foreign exchange contributors to the State, namely: in 2011 and 2012 ranked V, in 2013 to 2015 ranked fourth position [1]. In 2016 the tourism sector became the second largest foreign exchange earner after the palm oil industry [2]. This rapid development in the tourism sector has become an indicator of the urgency of the government's attention in realizing the implementation of integrated and sustainable tourism. The movement of places to get food and avoid the disaster has been a human instinct since the time of Egyptian. Human movement is preferred by the group leader (primus interperes) but within a limited distance (narrow territory) [3]. In subsequent developments, the movement of people or groups of people assisted by the conventional means of transportation, namely the transactional strategy of ordering and marketing of transportation services conducted with faceto-face between parties directly. However, such circumstances have changed since the advent of technology business transactions of tourism transportation services that use internetbased applications. This type of transport system is commonly known as "online-based transport/application-based transportation/online transportation". The online application is paired on mobile phone actors' transportation services and users of transportation services. In short, the intended application is a media/container meeting as well as transactions agreement between the transport service providers and users of transportation services [4].

Pribadiono in the Lex Journalica journal conducted a study concerning business competition taking place after the emergence of an online-based transport system and found that the previous competition in the form of physical then shifted into cyberspace-based, resulting in unbalanced access in obtaining economic resources for transportation business actors both conventional and online [5]. Along with this, Warsioto in his writing on "Proceeding Seminar Nasional Multi Disiplin Ilmu \& Call for Papers Unisbank Ke-3 (Sendi_U 3) 2017" examines the Legality of Online Based Mode and Its Impact for the Government of Joko Widodo. In his study Warsioto found that previously the government was not yet fully able to provide adequate employment for its citizens. The presence of online-based mode of transportation can actually be a solution for the government to stretch the movement of the economy of the people whose estuary will create a situation of a country conducive atmosphere [6]. Building upon the above research results it can be concluded that the existence of online-based transport model is currently recognized by the government, but raises a business competition model different from the physical form, which shifts to the form of cyberspace. Moving the facts, the paper discusses the theoretical model of business competition that is appropriate to be applied in an effort to prevent unhealthy business competition between business actors of conventional transportation services and online-based transportation through the application of the principle of economic democracy Pancasila (the five principles of the Indonesian republic).

Through this research, it is expected that theoretical ideal model will be obtained to be applied in avoiding unfair 
business competition between tourism service business actors, both online and conventional. By applying the principle of economic democracy of Pancasila, the expected estuary is the realization of justice in access to economic resources in the field of transportation services. In line with these objectives, the research design used in this paper is normative juridical. The approaches used are conceptual and legislative approaches to tourism and legal materials related to tourism and transportation are analyzed by legal theory and the results are presented by qualitative descriptive method.

\section{METHOD}

Grounded on this study, this paper is designed to reveal the economic democracy principles in anticipating the global business competition of tourism transportation by using normative juridical methods oriented towards conceptual and legislation approaches to transportation and fair business competition.

\section{RESULT AND DISCUSSION}

\section{A. Online-Based Transportation in Tourism Business}

Efforts to define tourism give rise to various opinions considering tourism is a multi-faceted concept. It is not easy to define the concept of tourism that can survive in various conditions and perspectives. Tourism Terminology based on Word Tourism Organization (WTO) conceptualized as follows:

"Given to activity that occurs when tourist travel. This encompasses everything from the planning of the trip, the travel to the place, the stay itself, the return and the reminiscences about it afterwards. It includes the activities the travel undertakes as part of the trip, the purchases bought, and the interactions that occur between host and guest. In sum, tourism is all of the activities and events that occur when a visitor travels" The definition provides restrictions on the term tourism that includes all activities and events that occur when visitors travel. A visitor is a term that refers to a person or several people who travel (visitor who travels). So for each individual to be said to do tourism activities (tourism) some indicators that distinguish one's travel activities as tourists or non-tourists needed. The journey of a person or a few as a traveler can be distinguished in trans-state travel (international) and travel within (domestic) country. International travel is intended as an activity or movement where a person passes cross country borders (international) with the purpose of a particular purpose. The understanding of international travel can be seen in some international instruments as follows:

- League of Nations: "any person visiting a country, other than that in which he usually resides for a period of at least 24 hours. The following individuals are considered tourists: persons traveling for pleasure, for family reason, for health, business, etc."

- International Union of Official Travel Organization (IUOTO): "any person traversing a country even for a period of more than 24 hours, without stopping, or a person traversing a country during a period of less than
24 hours, provided that the stops made are of short duration and for other than tourism purposes".

- United Nations' Roma Conference: “...that visits could be for the following reason: 1) leisure, recreation, holiday, sport, health, study, religion; 2). business, family, friends, mission, meeting... a tourist would be someone who traveled for business or for pleasure as long as the individual did not receive money from the country visited".

- United Nations Department of Economic and Social Affairs: "... who visited a given country from abroad (what we might call inbound tourists) and those who went abroad on visits from a given country (outbound tourists) [7].

Furthermore, domestic travel can be seen in the landmark studies of the National Tourism Resources Commission published in the United States, which indicates that: "domestic tourist is one of those traveling away from home for at least 50 miles one away". To be categorized as foreign tourists, some indicators must be met so as to be distinguished from domestic tourists. The indicators referred to include time over 24 hours; in terms of purposes of domestic tourism activities can aim for fun, vacation, sports health, family, business, friends, etc. Distinguishing elements with domestic tourists of course so that tourists can achieve the objectives as previously disclosed, one must travel for a certain distance. If reflected by the validity of the concept of domestic tourists in America, of course the concept of domestic tourists in Indonesia needs to be studied further to avoid error in the formulation of norms. Concerning to the description of the definition of tourism and tourists above, it is indeclinable that tourism is a unified form of system in which various components are contained in the system. Implicitly, in order for a person or group of people to be categorized as "doing tourism", there are many goals that can motivate their travel activities. Different tourist destinations in the tour make the flow of world tourism development leads to the provision of goods and services that can support the needs of tourists during the tour, ranging from planning, travel process to the memories of the trip. Although tourism is not an industry, it is unavoidable that within the tourism sector there are industries that form tourism.

In Law no. 10 of 2009 on Tourism (hereinafter referred to as Tourism Law), tourism is defined as a variety of tourism activities supported by various facilities and services provided by the community, businessmen, government and local government. Furthermore, through Article 1 point 7 , it is conceptualized that tourism business is a business that provides goods and/or services for meeting the needs of tourists and the implementation of tourism. The word 'effort' in Big Indonesian Dictionary is defined as: 1) activity by exerting energy (mind or body) to achieve a purpose; work (deeds, initiatives, endeavors, effort) to achieve something; 2) trading activities (for profit); trading; company. The word "effort" in the tourism context as Article 1 number 7 of Tourism Law describes money oriented activities as well as activities in the purpose of management of objects (tourist attraction and tourist area). Concerning tourism business is further stipulated in Article 14 of Tourism Law that tourism business covers several entities 
such as: tourist attraction; tourism areas; travel transportation services; travel services; food and beverage services; accommodation provision; organizing entertainment and recreation activities; organizing meetings, incentive trips, conferences and exhibitions; tourism information services; tourism consultant services; guides services; tourist tirta; spa.

Tourism business undertaken to provide goods and/or services for the needs of tourists would need to be clarified. A business is built with profit-oriented (profit of economy), whereas goods and/or services that become a product of a business are not just limited to certain market share (tourists). In detail, it can be said that the economic and business law in Indonesia does not regulate the market share of a business because considering the market share is the economic freedom of business actors. A business that provides goods and services for the fulfillment of tourist needs may at the same time provide goods and/or services for the needs of others other than tourists. If so, every business on all scales (micro, small, medium and large) without boundary to place and quality can be classified as a tourism business. Looking back at the conceptualization of tourism business in Article 1 point 7 of the Law on Tourism, if interpreted grammatically $[8,9]$ it can be said that the business of online transportation services, business of conventional transportation services (business without registration procedure) can enter in service provider category. There is a possibility for a traveler to use transportation services without permission to meet their needs. Back again to the nature of the needs of tourists, whatever type of activity needs always leads to satisfaction for the fulfillment of travel destinations. Although without a formal permit, if the online or conventional transportation is able to provide satisfaction of the destination of tourists, is it impossible for the two types of transportation to be a scope of understanding of tourism business?

The formulation of Article 15 paragraph (1) reads: "To be able to carry out tourism business as referred to in Article 14, tourism entrepreneurs shall register their business firstly to the Government or Regional Government". Such arrangements narrow the scope of the concept of tourism transportation services by having to grasp the permit from the government. Referring to the concept of tourism business Article 1 number 7 of the Law on Tourism can be online and conventional transportation with no permission to be part of tourism business. It is true that the limitation of tourism business concept has been regulated in Article 15 paragraph (1) and Tourism Ministry Regulation (PermenPar) 18/2016. In fact, online and conventional transportation with no stretch at a time, also operates to meet the needs of tourists. Therefore, the policy approach in tackling the potential for the emergence of intersection of interests (in the form of unfair business competition) between business actors of transportation services to the field of tourism in Indonesia is very necessary.

\section{B. Principles of Economic Democracy as a Business Competition Strating-point for Tourism Transportation Services}

The orientation of the implementation and development of tourism in Indonesia is shown in Article 3 of Tourism Law which reads: "Tourism serves to meet the physical, spiritual and intellectual needs of every tourist with recreation and travel and increase the state's income to realize people's prosperity". The final estuary of the organization of tourism is a just and equitable welfare felt by the people. The concept of justice (justice) and evenly intended to avoid a tourism atmosphere colored by liberal ideology that is identical with capitalism. Freedom of effort led to the emergence of many entrepreneurs who wanted to derive direct economic implications from the tourism sector. Therefore, it is very important to redirect the policy orientation in the development of tourism business towards a prosperous society through healthy competitive conditions based on economic democracy.

Etymologically, democracy comes from the term "demos" meaning people and "cratein" means to govern, so democracy is a government held by the society [10]. In the context of the term "economic democracy" there is a shift in the definition of the notion of democracy independently. Before that, it would be appropriate to examine the nature of economics as a science. Through philosophical alignment, it can be seen that human beings are rational beings, always wishing for improvement / improvement (maximization) for the sake of his welfare. To achieve both they can do things that considered useful [11]. In line with Bentham's utilitarianism which states that human beings actually have a principle of seeking as much pleasure as possible. Economy is technically a rational human action based on its orientation towards happiness. Happiness is an abstract entity that can only be felt with subjective indicators, so in its development the idea of using numbers (numeric) as an indicator of happiness arises. A more objective indicator of numbers that then shifts into subjectivity is a 'taste' indicator as a measure of happiness. Sargent points out some elements that generally exist in an ideology called democracy, as follows: "element of democracy or at least of those elements normally considered significant. They are:

- Citizen involvement in political decision making

- Some degree of equality among citizens

- Some degree of liberty or freedom granted to or retained by citizens

- A system of representation

- An electoral system-majority rule [12].

Freedom is a term much discussed by Stuart Mill in his book "On Liberty". Briefly Mill's thought leads to individual freedom to realize the individual's happiness itself, because the happiness of society can consist of the happiness of most individuals and not the happiness of all individuals. Therefore, measuring the achievement of individual happiness that can be done to pay attention to the happiness of other individuals to avoid collapse is necessary. Public happiness is created by bringing together the happiness of each individual [13]. Economic democracy can be interpreted as the individual's freedom to choose rationally all matters related to his economy. In this case, the right of the state to regulate the form of policy (establishing, overseeing and enforcing) the law in the field of economy is run to realize fair business competition. Pancasila is an ideology of the nation and state of Indonesia. Pancalisa as ideology is not rigid and closed but open. This implies that the 
ideology of Pancasila is actual, dynamic, anticipative and always able to adjust to the development of the times [14]. In line with Pound's opinion that law serves as a social engineering tool, to establish economic democracy, government regulation in the form of a rule of law that contains orders and restrictions in creating a healthy business competition atmosphere is required, in this context a healthy business competition atmosphere in tourism enterprises.

In the context of tourism transportation services business, economic democracy is realized through the provision of opportunity to every business actor to do business in the field of tourism transportation services as long as not contrary to the public interest. The principle of public interest is a "bulkhead" that is supposed to prevent conflicts in the interests of business actors of tourism transportation services, or between business actors of tourism transportation services with public transport service business actors. The Government in such a position plays a central role as the formulator and implementer of Indonesian tourism development law politics. This is in accordance with Pound's framework that law is used as a tool for social engineering. Concretely, the existence of online transportation as a tourism transportation service business must be guided by several government policies, among others: first, the online transportation service must follow the licensing procedure as the provisions of the requirement to become a tourism transportation service business; secondly, the government launched a system of cooperation between conventional transportation and online transportation as a licensed transportation service business to support tourism; third, the government can empower local transportation service entrepreneurs (conventional) licensed in the tourism area by forming containers and assisting the marketing and ordering system; and fourth, the government issued a policy in the determination of tariffs for transportation services for tourists so for the sake of fair business competition among business actors transport services especially to tourists. The description of the solution is solely aimed at realizing the equality of all transport service business actors in order to gain access to marketing in tourism destinations of tourism destinations.

\section{CONCLUSION}

In order to avoid unfair business competition in the form of a monopoly between the online and conventional tourism transportation services, the government should play a dominant role in the field of public policy based on the principle of economic democracy that values Pancasila. concretely, the role of government in directing the development of tourism transportation services business can be done, among others by: online transportation services must follow the licensing procedures as the provisions of the requirements to become a business of tourism transportation services; the government launched a system of cooperation between conventional transportation and online transportation as a licensed transportation service business to support tourism; the government can empower locally licensed (conventional) transportation service entrepreneurs in the tourism area by forming a container and assisting the marketing and ordering system of the government; and the government issued a policy in the determination of tariffs for transportation services for tourists in order to create a healthy atmosphere of business competition between business actors of transportation services, especially in tourism sector.

\section{ACKNOWLEDGEMENT}

The author would like to thank all the parties who have helped and contributed in the writing of this article, both those who contribute in the form of funding and critical ideas. Hopefully this paper can be useful theoretically and practically for the addition and development of knowledge, especially in the field of legal science.

\section{REFERENCES}

[1] Kemenpar, Rangking Devisa Pariwisata terhadap Komoditas Ekspor Lainnya, http://www.kemenpar.go.id/userfiles/devisa2011-2015.pdf, retrieved Januari 30, 2018.

[2] Detik.com, Tiga Tahun Jokowi-JK, Pariwisata Sumbang Devisa Terbesar Kedua, https://finance.detik.com/berita-ekonomi-bisnis/d3687715/tiga-tahun-jokowi-jk-pariwisata-sumbang-devisa-terbesarkedua, diunduh 30 Januari 2018, 2017.

[3] J. Swarbrooke and S. Horner, Business Travel and Tourism, Linacre House, Jordan Hill, Oxford, p. 15, 2001.

[4] W. Andika, Aspek Hukum Bisnis Transportasi Jalan Online, Sinar Grafika, Jakarta, 2016.

[5] P. Agus, Transportasi Online Vs Transportasi Tradisional Nononline Persaingan Tidak Sehat Aspek Pemanfaatan Aplikasi Oleh Penyelenggara Online, https://media.neliti.com/media/publications/146691-ID-transportasionline-vs-transportasi-trad.pdf

[6] Warsito, Legalitas Moda Transportasi Berbasis Online Dampaknya Bagi Pemerintahan Joko Widodo, https://media.neliti.com/media/publications/171551-ID-legalitas-modatransportasi-berbasis-onl.pdf

[7] M. R. Christie, Global Text: Tourism, The International Business, Jacobs Foundation, Zurich, Switzerland,h.20, 2009.

[8] S. A. Dedi, Tafsir Hukum Positif di Indonesia, Tourism, Linacre House, Jordan Hill, Oxford, p. 15, 2011.

[9] Diantha, I. M. P., Metodologi Penelitian Hukum Normatif: dalam Justifikasi Teori Hukum, Prenada Media Group, Jakarta, 2016.

[10] Atmadja, I. D. G., Ilmu Negara: Sejarah,Konsep, Dan Kajian Kenegaraan,Setara Press, Malang, 2012.

[11] S. Fajar, Economic Approach to Law, seri II, Kencana Prenada Media Group, Jakarta, 2013.

[12] S. L. Tower, Contemporary Political Ideologies: A Comparative Analysis, The Dorsey Press,Chicago,Illinois. 1984.

[13] M. J. Stuart On Liberty, translated by Alex Lanur, OFM, Yayasan Obor Indonesia, Jakarta, h.xvii, 2005.

[14] Kaelan, Pendidikan Pancasila,Paradigma,Yogyakarta. 2014. 